\title{
Oral zinc sulphate in treatment of patients with thallium poisoning: A clinical therapeutic trial
}

\section{Talyum zehirlenmesi tedavisinde oral çinko-sülfat: Bir klinik tedavi çalışması}

\author{
Khalifa E. Sharquie ${ }^{1}$, Khalil I. Al-Hamdi ${ }^{2}$, Adil A. Noaimi ${ }^{3}$, Ahmed A. Al-Mohammadi ${ }^{4}$ \\ ${ }^{1}$ Scientific Council of Dermatology EVenereology-Iraqi Board for Medical Specializations \\ ${ }^{2}$ Department of Dermatology \& Venereology, College of Medicine-University of Basrah \\ ${ }^{3}$ Department of Dermatology \& Venereology, College of Medicine-University of Baghdad \\ ${ }^{4}$ Department of Dermatology \& Venereology, Basrah Teaching Hospital, Iraq
}

\begin{abstract}
Objectives: Thallium poisoning is usually associated with typical dermatological features simulating that of zinc deficiency. The aim of this study was to evaluate the role of oral zinc sulphate in the treatment of patients with thallium poisoning.
\end{abstract}

Materials and methods: This clinical therapeutic trial study was conducted in Departments of Dermatology of Baghdad and Basrah Teaching Hospitals from February 2008 - February 2010, where a total of 37 patients with thallium poisoning were enrolled.

A detailed history was taken from all patients and complete clinical examination was performed. All patients received zinc sulphate in a dose of $5 \mathrm{mg} / \mathrm{kg}$ three times a day few days before confirming the diagnosis of thallium poisoning. Thallium in urine had been measured using the colorimetric method and was positive in all patients. After confirming the diagnosis of thallium poisoning, thallium antidotes Prussian blue was given to 32 patients.

Results: Age range of 37 patients was 5-33 (24 5 5.3) years. The dermatological findings were mainly: anagen hair loss affected the scalp and limbs. Also, dusky ecchymotic red dermatitis like rash was observed on the face and dorsum of hands and legs, while neurological manifestations were mainly of peripheral neuropathy, were reported in 21 (55\%) patients. All patients but two responded promptly to a trial of zinc sulphate within few days.

Conclusion: Oral Zinc sulphate appears to be an effective and safe treatment for thallium poisoning particularly for skin and hair features and in reducing its lethal progression and complications. J Clin Exp Invest 2011;2(2):133-7

Key words: Thallium poisoning, oral zinc sulphate, treatment, Iraq

\section{ÖZET}

Amaç: Talyum zehirlenmesi genellikle çinko eksikliğini taklit eden tipik cilt lezyonları ile birliktedir. Bu çalışmanın amacı talyum zehirlenmesi bulunan hastaların tedavisinde oral çinko sülfatın rolünü değerlendirmektir.

Gereç ve yöntem: Bu klinik tedavi çalışması, Bağdat ve Basra Eğitim hastanelerinde Şubat 2008- Şubat 2010 tarihleri arasında, talyum zehirlenmesi olan 37 hasta dahil edilerek gerçekleştirildi.

Hastaların tümünden detaylı anamnez alındı ve tam bir klinik muayene gerçekleştirildi. Hastaların tümü, Talyum zehirlenmesi tanısı doğrulanıncaya kadar, $5 \mathrm{mg} / \mathrm{kg}$ günde üç kez oral çinko sülfat aldı. İdrarda Talyum kalorimetrik yöntemle ölçüldü ve hastaların tümünde pozitif bulundu. Talyum zehirlenmesi tanısı kesinleştirildikten sonra Talyum antidotu Prusya Mavisi 32 hastaya verildi.

Bulgular: Otuz yedi hastanın yaş ortalaması $24 \pm 5.3$ yıl (5-33 yaş arası) idi. Ana dermatolojik bulgu saçlı deri ve ekstremiteleri tutan anagen saç kaybı idi. Ayrıca hastaların ayak sırtı ve bacaklarında ve yüzlerinde kirli kırmızı ekimotik döküntü benzeri lezyonlar görüldü. Başlıca periferik nöropati olarak nörolojik belirtiler 21 (\%55) hastada görüldü. İki hasta dışında hastaların tümü oral çinko sülfat tedavisine bir kaç gün içinde cevap verdi. Klin Deney $\mathrm{Ar}$ Derg 2011;2(2):133-7

Sonuç: Oral çinko sülfat talyum zehirlenmesinde özellikle deri ve saç bulguları için ve komplikasyonları ve ölüme gidişi azaltmada etkili ve güvenli bir tedavi gibi gözüküyor.

Anahtar kelimeler: Talyum zehirlenmesi, oral çinko sülfat, tedavi, Irak

Yazışma Adresi /Correspondence: Prof. Khalifa E. Sharquie, Scientific Council of Dermatology \& Venereology-Iraqi Board for Medical Specializations, Medical Collection Office, P.O. Box 61080, Postal Code 12114, Baghdad, Iraq, Email: ksharquie@yahoo.co.uk Geliş Tarihi / Received: 26.01.2011, Kabul Tarihi / Accepted: 24.02.2011

Copyright (C) Klinik ve Deneysel Araştırmalar Dergisi 2011, Her hakkı saklıdır / All rights reserved 


\section{INTRODUCTION}

Thallium is a heavy metal that has qualities of a perfect criminal poison. Its salts are tasteless, colorless and odorless, that dissolve completely in liquids, which are rapidly absorbed, and defy detection on routine toxicological screens. Thallium has been the agent of choice in several criminal poisonings. ${ }^{1-3}$

Elimination half-life of thallium is long, due to its large distribution volume. The estimated half-life in humans is reported between 1-3 days after low doses and between 1-1.7 days under clinical therapy after ingestion or exposure by a possible lethal dose. Other groups have reported an elimination half-life between 8-30 days. Minimum lethal dose (LD50) of thallium in humans is also highly variable. Average lethal dose for thallium sulfate has been reported to range from $10-15 \mathrm{mg} / \mathrm{kg} .{ }^{4}$

Thallium poisonings are generally due to ingestion of the salts, but cases of inhalation of dusts or fumes from smelting, skin absorption and even from sniffing contaminated cocaine have been reported. ${ }^{5,6}$ It is used in the manufacture of electronic components, optical lenses, semiconductor materials, alloys, gamma radiation detection equipment, imitation jewelry, artist's paints, low temperature thermometers, and green fireworks. ${ }^{5}$

In some parts of the world it is still used for killing rodents and this may lead to inadvertent ingestion by humans. ${ }^{7}$ Thallium poisoning is rare in Western societies. It has occasionally been the tool for murder. ${ }^{8}$ Emsley mentioned that a person in the UK poisoned eight people and two of them died. ${ }^{1}$ An outbreak of thallium poisoning was reported in Baghdad in February 2008 where members of Iraqi Air Force Club and some of their children were poisoned by cake laced with thallium. Two of the children died, ${ }^{9}$ another two outbreaks of thallium poisoning were reported in Iraq at January 2009 to February 2010 where a total of thirty two patients that are evaluated. ${ }^{10}$

Its toxic effect is due to its ability to inhibit a number of intracellular potassium-mediated processes and legends formations with protein sulfhydril groups, inhibition of cellular respiration, interaction with riboflavin and riboflavin-based cofactors, and distribution of calcium homeostasis. ${ }^{1,4}$

The diagnosis of thallium poisoning is not very easy and requires chemical analysis to confirm it.
Demonstration of the presence of thallium in urine is the best diagnostic procedure available. ${ }^{4}$

Short-term exposure to thallium may induce hair loss, skin lesions, and damage to the nervous system. ${ }^{4,11-14}$ The clinical features of short-term thallium intoxication include gastrointestinal symptoms of nausea, vomiting, stomatitis, and diarrhea, followed by severe painful dysesthesia and paraesthesia in the distal limbs, erythematous rashes in the cheeks and perioral region, and hyperkeratosis with loss of hair in sub acute stage., ${ }^{2,3}$ In the long-term, complete hair loss and severe polyneuropathy have been noted. The severity of dermatological picture is supposed to be related to the severity of thallium intoxication. ${ }^{14}$

The combination of rapid, diffuse alopecia, with neurological and gastrointestinal disturbance is pathognomonic for thallium toxicity. The hair mount, showing a tapered or bayonet anagen hair with black pigmentation at the base, which may be highly diagnostic before the onset of alopecia. ${ }^{12}$

Zinc sulphate had been used in the treatment of many skin diseases such as cutaneous leishmaniasis ${ }^{15}$, recalcitrant viral warts ${ }^{16}$, Behcet's disease ${ }^{17}$, rosacea ${ }^{18}$. Perifolliculitis capitis abscedens et suffodiens ${ }^{19}$, alopecia areata and recurrent aphthous stomatitis ${ }^{20}$, and it was proved to be safe and effective.

The present work was designed to report the role of oral zinc sulphate in the treatment of thallium poisoning.

\section{MATERIALS AND METHODS}

This is a clinical therapeutic trial study that was carried out in the Departments of Dermatology of Baghdad and Basrah Teaching Hospitals from February 2008 to February 2010, where a total of 37 patients with thallium poisoning were included in the present work. Thirty two patients were seen at Basrah Teaching Hospital while the remaining 5 patients were examined at Bagdad Teaching Hospital.

A detailed history was done regarding the following points: age, sex, mode of intake, patient's presenting complaints, time of onset and full dermatological examination was performed looking for skin and hair manifestation and other systemic involvement concentrating on GIT and CNS organs. Thirty seven patients received oral zinc sulphate 
capsule (MERK, France) in a dose of $5 \mathrm{mg} / \mathrm{kg}$ three times a day few days before confirming the diagnosis of thallium poisoning and before using any thallium antidotes (e.g. Prussian blue). Thallium in urine has been measured in the Poisoning Consultation Center using the colorimetric method and was positive in all of patients. After confirming the diagnosis of thallium poisoning, 32 patients were examined in Basrah Teaching Hospitals received oral thallium antidotes (Prussian blue) (ABBOTT, France) in a dose of $1 \mathrm{~g}$ three time a day followed by $250 \mathrm{mg} /$ $\mathrm{kg}$ /day in divided qid as a maintains treatment until the 24-hour urine thallium return to normal range (0-5 mcg/day). While the remaining 5 patients that were seen in Baghdad Teaching Hospital did not take Prussian blue because the diagnosis of thallium poisoning was late.

Formal consent was taken from each patient or their parents prior to their inclusion in this work; in addition the approval of the ethical Committee of Scientific Council of Dermatology and Venereology of Iraqi Board for Medical Specializations was also obtained.

\section{RESULTS}

Thirty seven patients with thallium poisoning were evaluated. Including 26 males and 11 females (male/ female; 2.36/1), their ages ranged from 5-33 years with a mean age of $24 \pm 5.3$ years.

All patients who ingested thallium accidently developed immediate onset signs and symptoms of thallium intoxication including nausea, vomiting and diarrhea in $21(55 \%)$ of them followed by mental and peripheral neurological complaints and within two weeks all patients of this group developed skin manifestations mainly severe hair loss in diffuse and patchy forms of anagen type, affecting mainly scalp and body hair.

Anagen hair loss was obvious for all the patients (Figure 1), it started in the second and third week, as diffuse or patchy hair loss involving mainly the scalp and the lower limbs. The affected hair was either broken at the surface of the skin in black dots like pattern or diffusely lost, presenting as diffuse hair thinning or remarkable total alopecia. The remaining hairs at the affected area were easily plucked and they were in typical anagen phase. Microscopically the roots were pigmented having anagen features.
The skin rash appeared in all patients in the first week, it was dermatitis-like picture with ecchymotic dusky red color that covered the face especially around the mouth and the limbs mainly on the dorsa of both hands simulating horse shoe appearance and that of acrodermatitis enteropathica or pellagra pictures (Figure 2). Acneiform rash of the face was seen in two patients.

The neurological findings were observed in $21(55 \%)$ patients as peripheral neuropathy with marked leg and foot tenderness and paraesthesia which developed with in 2 to 4 days of thallium intoxication, muscular weakness was noted in most of those patients especially of the lower limbs and of variable severity.

Psychiatric findings were seen in $4(10 \%)$ cases mainly in a form of personality changes, depression and apathy while others presented with anxiety and acute agitation.

All 37 patients were given $5 \mathrm{mg} / \mathrm{kg}$ (t.d.s) oral zinc sulphate as considered as a zinc deficiency before the definite diagnosis of thallium poisoning was established and before using oral Prussian blue. Surprisingly 35 out of 37 cases improved markedly within few days especially regarding the horse shoe like rash on the dorsa of their hands, alopecia and neuromuscular involvement. This improvement started few days before given Prussian blue thallium antidotes. Thirty two patients were examined in Basrah Teaching Hospital did receive oral thallium antidotes (Prussian blue), while the remaining 5 patients that were seen in Bagdad Teaching Hospital did not taken Prussian blue because the diagnosis of thallium poisoning was late.

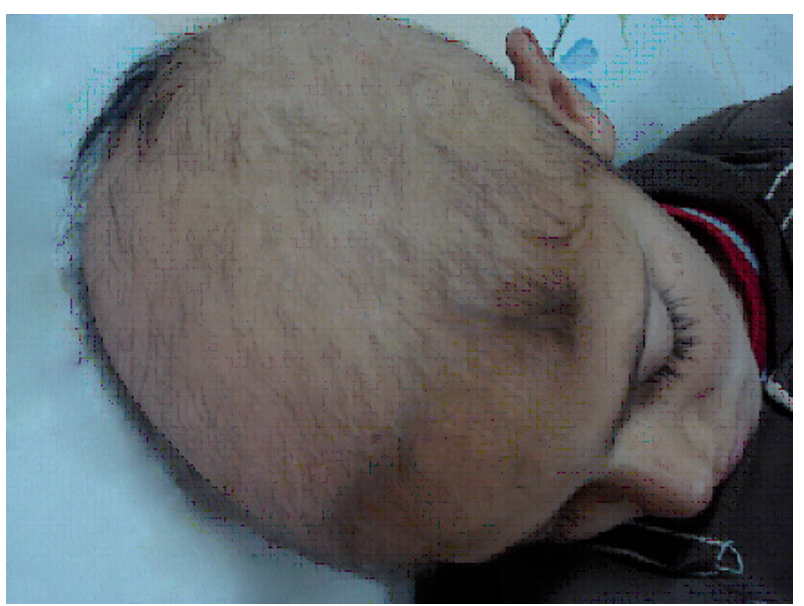

Figure 1. Anagen hair loss 


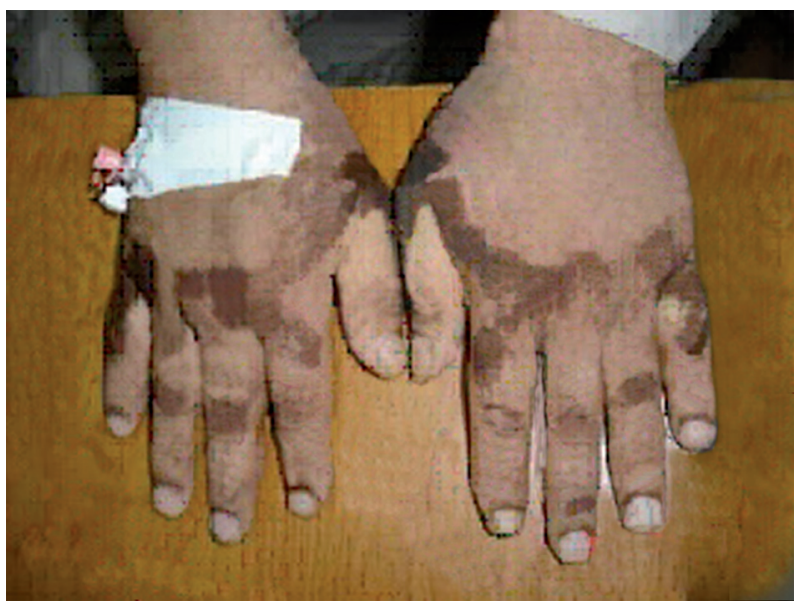

Figure 2. Dermatits like lesions on dorsum of the hands

The patients were kept on this treatment for two weeks and no relapse was reported after complete clearance, whereas the remaining two cases who presented later with severe neurological symptoms and in spite of their dramatic response to the oral zinc sulphate regarding their dermatological symptoms, and after establishing the diagnosis of thallium poisoning they received adjuvant oral Prussian blue, but unfortunately died due to respiratory failure.

\section{DISCUSSION}

The International Program on Chemical Safety (IPCS) of the World Health Organization (1996) has produced a detailed Environmental Health Criteria Monograph on thallium. The monograph concluded that in the general population, the total intake of thallium has been estimated to be less than 5 microgram per day, mostly from foodstuffs, and that this does not constitute a threat to health. ${ }^{1}$

Many outbreaks of thallium poisoning occurred in Iraq as a result of criminal or accidental ingestion of thallium contaminated food during 2008-2010, the skin and neurological findings were the dominant pictures. ${ }^{10,21}$

In present work, thirty seven patients were evaluated during the period between 2008 and 2010 showed that the skin manifestations were very characteristic of thallium poisoning, especially the severe anagen alopecia and dermatitis like picture. These features had been similarly reported by other studies 21 and are so, characteristic that can lead into the right diagnosis. Other diagnoses that might be mistaken with thallium poisoning are acquired zinc deficiency, pellagra and erythema multiforme. ${ }^{15}$
All cases in this work improved dramatically within few days after treatment with oral zinc sulphate. The similarities of skin manifestations between thallium poisoning and that of pellagra and/or zinc deficiency, raise a question, does thallium poisoning interact in away or another with zinc, niacin or riboflavin base factor metabolism. Therefore, it causes their deficiency resulting in clinical features simulating that of these elements' deficiency. These possibilities may explain why a zinc supplement is helpful for those patients with thallium poisoning. So these points should be considered in any further studies.

On the other hand, the dramatic response of patients with thallium poisoning to oral zinc sulphate therapy prior to the use of any specific thallium antidotes and within a short period indicates that the response is attributed basically to the use of zinc sulphate, rather than to any other specific treatments, particularly for hair and skin manifestations and possibly other clinical features.

Moreover, the dramatic improvement of all cases after treatment with oral zinc sulphate necessitates further studies to identifying the mechanism of its action including animal study that is strongly recommended.

The possible mechanism of action of zinc sulphate in the treatment of thallium poisoning may be through one or all of the following mechanisms. Zinc may also impact hair and skin biology via its long-recognized, potent and immunomodulatory effects. ${ }^{22}$ Zinc exerts an indirect antioxidant action by induction of some substances that serve as the ultimate antioxidant, these substances are "metallothionein". ${ }^{23}$ Zinc is an essential cofactor for over 300 enzymes [zinc metalloenzymes], many of which (e.g. alkaline phosphatase, dopachrome tautomerase, metallothionein and metalloproteases) exert important functional activities in the hair follicle. ${ }^{24}$ Zinc is important for DNA stability and repair-parameters of evident importance in hair biology, since the epithelial hair matrix is one of the most rapidly proliferating and most damage-sensitive tissues in the mammalian organism. ${ }^{25}$

Zinc may increase the renal elimination of thallium and/or possibly interfere with its absorption from the gastro intestinal tract so ,that zinc act as chelating agent. ${ }^{1,4}$ Zinc is an essential cofactor for many body enzymes that it may counteract the ef- 
fect of thallium on the riboflavin and riboflavin cofactors. So this may explain the dermatological and neurological improvement in patients with thallium poisoning after using oral zinc sulphate. ${ }^{24}$

In conclusion, oral zinc sulphate appears to be a safe and effective treatment for thallium poisoning especially in its early stages particularly before establishing the diagnosis and to be used as an adjuvant therapy with thallium antidotes after establishing the diagnosis of thallium poisoning in order to reduce or prevent its lethal progression and complications.

\section{REFERENCES}

1. Peter ALJ, Viraraghavan T. Thallium: A review of public health and environmental concerns. Environ Int 2005;31(4):493-501.

2. Desenclos JC, Wilder MH, Coppenger GW, Sherin K, Tiller R, Vanhook RM. Thallium poisoning: An outbreak in Florida,1988. South Med J 1992;85(11):1203-6.

3. Meggs WJ, Hoffman RS, Shin RD, Weisman RS, Goldfrank LR. Thallium poisoning from maliciously contaminated food. J Toxicol Clin Toxicol 1994;32(6):723-30.

4. Galvan-Arzate S, Santamaria A. Thallium toxicity. Toxicol Lett 1998;99(1):1-13.

5. Baldwin DR, Marshall WJ. Heavy metal poisoning and its laboratory investigation. Ann Clin Biochem 1999;36:267300 .

6. Insley BM, Grufferman S, Ayliffe HE. Thallium poisoning in cocaine abusers. Am J Emerg Med 1986;4(4):545-548.

7. Moore D, House I, Dixon A. Thallium poisoning: diagnosis may be elusive but alopecia is the clue. BMJ 1993;306(12):1527-9.

8. Rusyniak DE, Furbee RB, Kirk MA. Thallium and arsenic poisoning in a small Midwestern town. Ann Emerg Med 2002;39(2):307-11.

9. BBC News/Middle East/Poison cake kills Iraqi children (Iraqi Air Force Club), http://news.bbc.co.uk/2/hi/middle_ east/7237086.stm

10. Sharquie KE, Ibrahim GA, Noaimi AA, Hamudy HK. Outbreak of Thallium poisoning among Iraqi Patients: A case descriptive study. J Saudi Soc Dermatol Dermatol Surg 2010;7(2):112-7.
11. Kuo HC, Huang CC, Tsai YT, Chu CC, Hsieh ST, Chu NS. Acute painful neuropathy in thallium poisoning. Neurology 2005;65(3):302-4.

12. Feldman J, Levisohn DR. Acute alopecia: Clue to thallium toxicity. Pediatr Dermatol 1993;10(1):29-31.

13. Prick JJG. Thallium poisoning: Vinken DJ, Bruyn GW, eds. Handbook of Clinical Neurology: intoxications of the nervous system. Amsterdam: North-Holland Pub Co., 1979;239-78.

14. Lu CI, Huang CC, Chang YC, Tsai YT, et al. Short-term Thallium intoxication. Arch Dermatol 2007;143(1):93-8.

15. Sharquie KE, Najim RA, Al-Timimi DJ, Farjou IB. Oral zinc sulphate in the treatment of acute cutaneous leishmaniasis. Clin Exp Dermatol 2001;26(1):21-6.

16. Al-Gurairi F, Al-Waiz MM, Sharquie KE. Oral zinc sulphate in the treatment of recalcitrant viral warts: Randomized placebo controlled trial. Br J Dermatol 2002;146(3):423-31.

17. Sharquie KE, Najim RA, Al-Dori WS, Hayani RK. Oral zinc sulphate in the treatment of Behcet's disease: A double blind cross-over study. J Dermatol 2006;33(4):541-6.

18. Sharquie KE, Najim RA, Al-Salman HN. Oral zinc sulphate in the treatment of rosacea: A double blind, placebo controlled study. Int J Dermatol 2006;45(7);857-61.

19. James WD, Berger TG, Elston DM. Acne. In: Andrews' Diseases of the Skin Clinical Dermatology 10th ed. Philadelphia: Saunders Elsevier 2006:244-245.

20. Sharquie KE, Najim RA, Hayani RK, Al-Nuaimy AA, Maroof DM. The therapeutic and prophylactic role of oral zinc sulphate in management of recurrent aphthous stomatitis (RAS) in comparison with dapsone. Saudi Med J 2008;29(6):734-48.

21. Sharquie KE. No man is an island, Thallium poisoning with skin manifestations. Virtual Grand Round in Dermatology 2.0, http://vgrd.blogspot.com/2008/04/iraqi-reality. html? showComment=1209569400000.

22. Vallee BL, Falchuk KH. The biochemical basis of zinc physiology. Physiol Rev 1993;3(1):79-118.

23. Prasad AS. Zinc Disorders. In: Ston J (ed.): Dermatology, immunology and allergy CV Mosby and Co St Louis, 1995:759-65.

24. Handjiski BK, Eichmuller S, Hofmann U, Czarnetzki BM, Paus R. Alkaline phosphatase activity and localization during the murine hair cycle. BJD 1994;131(3):303-10.

25.Paus R, Peker S. Biology of hair and nail. In: Bolognia JL, Jorizzo JL, Rapini RP, eds. Dermatology. London: Mosby Wolfe, 2003:1007-1032. 